\title{
ANALISIS PREFERENSI KONSUMEN TERHADAP PAKET ATRIBUT SPESIFIKASI PRODUK SEBAGAI COMPROMISE EFFECT TERHADAP PEMBELIAN NOTEBOOK
}

\author{
Albari \\ Fakultas Ekonomi Universitas Islam Indonesia \\ Dewi Amalia \\ Magister Manajemen Universitas Islam Indonesia
}

\begin{abstract}
Abstrak
Penelitian ini bertujuan menguji perbedaan preferensi konsumen dan perbedaan tingkat kepentingan atribut paket spesifikasi sebagai compromise effect berdasarkan karakteristik konsumen pada pembelian notebook di Yogyakarta dengan menggunakan uji nonparametik chi-square. Sampel yang digunakan adalah 96 responden dengan lokasi penyebaran di kampus, distributor computer dan tempat-tempat umum. Hasil studi menunjukkan terdapat fenomena compromise effect di antara tiga paket spesifikasi atribut notebook yang diteliti dan monitor notebook merupakan atribut dengan tingkat kepentingan konsumen yang paling tinggi. Di samping itu, terdapat perbedaan yang signifkan untuk preferensi konsumen berdasarkan pada karakteristik gender konsumen.
\end{abstract}

Kata kunci: compromise effect, preferensi, kepentingan atribut.

\section{PENDAHULUAN}

Compromise effect merupakan fenomena perilaku konsumen untuk memilih produk atau merek yang posisinya berada di antara pilihan dalam suatu kelompok produk yang ingin dibeli. Fenomena compromise effect ini dapat diartikan sebagai kecenderungan konsumen untuk menghindari pilihan yang mempunyai atribut ekstrim (Kivetz, Netzer and Srinivasan, 2004a), misalnya konsumen menghindari merek yang paling mahal, paling baik kualitasnya, paling cepat atau sebaliknya.

Akhir-akhir ini fenomena compromise effect sedang menjadi pusat perhatian, baik peneliti maupun praktisi pemasaran. Dari sudut pandang riset, eksistensi compromise effect telah memberi pemahaman baru tentang perilaku konsumen yang tidak konsisten dengan teori dan model yang sudah ada. Bagi para praktisi pemasaran, compromise effect mempunyai implikasi yang berpengaruh dalam menentukan kebijaksanaan pemasaran, seperti positioning, branding, dan strategi kompetitif lainnya.

Fenomena ini perlu untuk dicermati oleh produsen, khususnya produsen komputer yang saat ini merupakan industri yang terus berkembang dengan pesat. Produsen dapat merancang strategi dengan melancarkan spesifikasi produk untuk menarik minat konsumen. Komputer dapat berfungsi sebagai sarana penunjang pendidikan, pekerjaan dan dapat pula sebagai sarana hiburan, bahkan menjadi media telekomunikasi yang praktis selain telepon seluler.

Komputer yang biasa digunakan ada dua macam, yaitu Personal Computer 
(PC) dan notebook (Laptop). Fungsi-fungsi dasar keduanya hampir tidak ada perbedaan. Keunggulan notebook adalah pada kemampuannya untuk dapat memenuhi kebutuhan bagi seseorang yang sering bepergian, karena sifatnya yang mudah dibawa-bawa. Sedangkan kekurangan utama notebook, apabila dibandingkan dengan PC adalah pada harganya yang mahal, dan umumnya spesifikasi yang sudah ditetapkan dari produsen. Karena itu konsumen relatif tidak dapat menentukan spesifikasi komponen yang dipasang dalam notebook tersebut. Dengan kata lain konsumen hanya dapat memilih notebook dengan spesifikasi yang paling mendekati spesifikasi keinginannya.

Menurut Kotler and Keller (2006) salah satu cara untuk menarik pelanggan dan mengungguli pesaing adalah dengan memberikan produk yang sesuai dengan keinginan dan serta memuaskan konsumen. Berkaitan dengan notebook, perbandingan spesifikasi yang ditawarkan oleh masingmasing produsen adalah cara untuk menarik pelanggan dan mengungguli pesaing serta untuk memperluas pangsa pasarnya.

Menurut Kuswanto (2006), dalam melakukan pembelian notebook, konsumen seringkali mempertimbangkan beberapa hal yang mempengaruhi mereka, faktor-faktor yang mempengaruhi dalam proses pembelian dianggap penting oleh konsumen untuk dipertimbangkan dalam pemilihan sebuah notebook, antara lain faktor harga, berat, hard disk, baterai, sistem operasi, prosesor, VGA card, dan memori.

Untuk dapat memenangkan pasar di tengah persaingan yang begitu ketat, dengan menawarkan paket spesifikasi notebook yang sesuai untuk dapat memuaskan konsumen, maka paket spesifikasi dalam pembelian notebook ini perlu untuk di teliti, terutama yang berkaitan dengan atribut spesifikasi pembelian notebook dengan compromise effect.

\section{KAJIAN PUSTAKA.}

Chang and Liu (2008) menyatakan bahwa ketika konsumen harus mengambil keputusan tentang atribut di bawah situasi ketidakpastian, mereka sering memilih dengan pilihan kompromi. Pernyataan tersebut menguatkan penemuan Sheng, Parker and Nakamoto (2005), yang berhasil menguji minimalisasi terjadinya expectedloss di bawah ketidakpastian keputusan yang berdasarkan pada mekanisme compromise effect, karena suatu pilihan kompromi dapat mengurangi konflik hubungan dengan cara merelakan suatu atribut untuk memperoleh yang lain dan menguatkan kombinasi antar atribut.

Compromise effect menunjukkan keuntungan suatu merek ketika merek tersebut dijadikan konsumen sebagai merek yang dipilih dibandingkan pilihan ekstrim dalam sekelompok merek tertentu (Marketing News, 2004). Lippert (1979) beranggapan bahwa kualitas dan produktivitas bisa dipandang sebagai beban dan diperlakukan sebagai suatu kompromi untuk mengurangi biaya per unit produk. Sedangkan Passavant (1980) menyatakan bahwa dilakukannya pendekatan kompromi dapat mengembangkan kekuatan dari perbedaan manajer dan personal kreatif untuk menetapkan sasaran dan ukuranukuran dalam mengevaluasi produk akhir.

Lebih jauh compromise effect dibahas oleh Simonson (1989) dengan menggunakan pendekatan psikologi sosial untuk memahami perilaku konsumen. Menurutnya, dalam memilih produk, konsumen tidak semata-mata melihat utilitas atau kepuasan yang diperoleh dari produk tersebut, tetapi juga memperhitungkan penilaian orang lain pada produk pilihannya. Konsumen akan memilih produk yang dapat menyeimbangkan kepuasan yang diperoleh dari mengkonsumsi produk tersebut dan persepsi orang lain terhadapnya. Oleh karena itu dalam pemilihan produk, 
konsumen membutuhkan alasan sebagai pembenaran atas pilihannya.

Menurut Simonson (1989) kebutuhan akan pembenaran ini merupakan refleksi dari hasratnya akan penghormatan atas diri sendiri atau self-esteem, menghindari penyesalan dalam pemilihan produk, ketidakseimbangan mental, dan persepsi orang lain terhadap dirinya sebagai pembeli yang rasional. Di samping itu disebutkan bahwa konsumen tidak selalu tahu secara sempurna atribut-atribut yang terkandung dalam suatu produk seperti kualitas, daya tahan, dan fungsi dari produk tersebut. Ketidakpastian ini menyebabkan konsumen cenderung untuk memilih produk yang memiliki atribut menengah dan bukan produk yang memiliki atribut yang ekstrim. Pendapat tersebut dikuatkan oleh Chang and Liu (2008), yang membuktikan bahwa compromise effect sebagai pilihan menengah berasal dari hubungan berbagai atribut yang menunjukkan bahwa suatu pilihan terlihat menjadi lebih menarik.

Sedangkan penelitian yang dilakukan Kivetz, Netzer, dan Srinivasan (2004a) menggunakan dasar sebuah model pemilihan produk yang memasukan compromise effect dalam rangka menyelidiki banyaknya konsumen yang berperilaku secara compromise effect. Dalam model itu diasumsikan bahwa kepuasan mengkonsumsi suatu atribut dari suatu produk adalah fungsi convex dari atribut tersebut. Asumsi ini digambarkan dalam 3 alternatif hubungan, yaitu hubungan antara kualitas dan utilitas, hubungan antara harga dan utilitas, serta hubungan atribut yang berada di antara dua pilihan lain. Hubungan yang terakhir memberikan kepuasan yang paling tinggi dan memiliki probabilitas tinggi untuk dipilih.

Kivetz, Netzer, dan Srinivasan (2004a) juga membuktikan bahwa model yang memasukan compromise effect mempunyai akurasi yang lebih tinggi daripada model-model tradisional seperti logit model. Ini membuktikan bahwa compromise effect adalah faktor yang signifikan bagi konsumen dalam memilih brand. Sementara itu, dalam penelitiannya yang lain, Kivetz, Netzer and Srinivasan (2004b) mengembangkan model compromise effect yang telah mereka lakukan sebelumnya tersebut dengan menambahkan aspek teknologi dan konteks subyek business-to-business (B2B).

Chuang at al (2007) menyatakan bahwa pilihan konsumen pada suatu merek sering dipengaruhi oleh banyak faktor. Penelitian Mourali, Bockenholt and Laroche (2007) menunjukan bahwa konsumen yang mempunyai sifat kehati-hatian lebih sensitif terhadap compromise effect dan kurang sensitif terhadap pengaruh daya tarik produk dibandingkan dengan konsumen yang lebih memperhatikan promosi. Di samping itu, jika dihubungkan dengan produk, konsumen yang hati-hati lebih tertarik dengan compromise effect dibandingkan dengan memilih merek yang mempunyai suatu atribut yang dominan, sedangkan produk yang dihubungkan dengan promosi lebih menarik disampaikan dengan pilihan atribut yang dominan dibandingkan compromise effect. Secara empiris Sheng, Parker and Nakamoto (2005) membuktikan bahwa terdapat pengaruh negatif kebiasaan konsumen dengan produk dan atribut penting terhadap compromise effect.

Sementara itu, Chuang and Yen (2007) menunjukkan bahwa informasi produk, seperti asal negara produk, sering mempengaruhi pilihan konsumen. Hasil penelitiannya menunjukkan bahwa ketika informasi asal negara produk mempunyai citra negatif, maka daya tarik produk dan compromise effect juga akan berkurang. Sedangkan Chuang at al (2007) lebih menfokuskan pada penghargaan konsumen terhadap kualitas produk. Hasil penelitiannya menunjukkan bahwa, ketika 
kualitas suatu produk di bawah tingkatan penghargaan konsumen, maka compromise effect berkurang.

Lebih jauh Lin at al (2007) membuktikan, ketika konsumen di bawah tekanan untuk memilih, pilihan seseorang tentang suatu produk dengan compromise effect lebih lemah dibandingkan dengan pengaruh daya tarik produk. Sedangkan Dhar, Menon and Maach (2004) menunjukkan bahwa compromise effect memberikan pemecahan yang lebih kompleks dalam proses dan pembelian produk secara institusional dari pada pembelian pribadi.

Di samping itu hasil penelitian eksperimental tentang compromise effect, Wernerfelt (1995) membuktikan perilaku konsumen untuk menggunakan data pasar dalam membuat kesimpulan tentang kegunaan produk, serta untuk mengambil keputusan tentang penilaian pribadi konsumen pada alternatif porto folio pasar dan beberapa informasi tentang perasaan relatif mereka.

Gambar 1 menunjukkan ilustrasi yang menggambarkan compromise effect dalam sebuah pemilihan produk di antara sekumpulan pilihan dengan dua buah atribut produk.

Pada Gambar 1 juga ditunjukkan contoh sederhana dari tiga paket (kelompok) pilihan produk atau merek yang dikeluarkan oleh seorang produsen. Produsen bisa mengeluarkan produk yang memiliki paket spesifikasi yang relatif sama satu dengan yang lain. Sedangkan untuk atribut pertimbangan, seperti atribut $\mathrm{v}$ dan atribut w, merupakan paket spesifikasi produk. Pada paket 1 terdapat A sebagai spesifikasi yang ekstrim, sedangkan pada paket 3 sebagai spesifikasi ekstrim adalah E. Jika seorang konsumen tidak mampu (bersedia) memilih paket 1 atau paket 3 , maka ia akan berusaha untuk memilih paket 2 sebagai paket compromise effect. Dengan kata lain dapat dikatakan bahwa paket-paket tersebut baik yang merupakan kategori pemilihan maupun penolakan konsumen melibatkan preferensi tentang compromise effect konsumen.

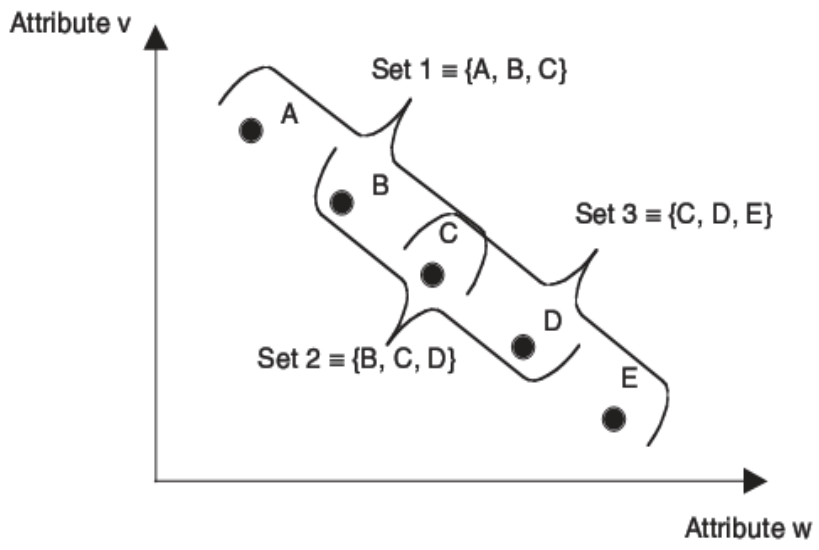

Gambar 1: Ilustrasi Compromise Effect (Kivetz, Netzer and Srinivasan, 2004a) 
Preferensi konsumen merupakan keputusan konsumen untuk menyukai atau tidak menyukai sebuah pilihan berdasarkan penilaiannya terhadap produk (Mowen \& Minor, 2002). Pada dasarnya konsumen sangat berpegang erat pada preferensi mereka sendiri, yaitu mereka cenderung bertanya kepada diri mereka sendiri tentang sesuatu yang mereka sukai, dan kemudian menggunakannya sebagai titik tolak untuk memprediksi preferensi orang lain yang terdekat.

Menurut Simamora (2003) ada beberapa langkah yang harus dilalui sampai konsumen membentuk preferensi, yaitu:

1. Diasumsikan bahwa konsumen melihat produk sebagai sekumpulan atribut. Sebagai contoh sebuah komputer merupakan sekumpulan atribut yang terdiri dari monitor, hard disk, prosesor, dan sistem operasi. Konsumen yang berbeda mungkin memiliki persepsi yang berbeda tentang atribut lain yang relevan

2. Tingkat kepentingan atribut berbedabeda sesuai dengan kebutuhan dan keinginan masing-masing. Konsumen memiliki penekanan yang berbeda-beda dalam menilai suatu atribut yang paling penting. Konsumen yang daya belinya terbatas, kemungkinan besar akan memperhitungkan atribut harga sebagai yang utama.

3. Konsumen mengembangkan sejumlah kepercayaan tentang letak produk pada setiap atribut. Sejumlah kepercayaan mengenai merek tertentu disebut kesan merek.

4. Tingkat kepuasan konsumen terhadap produk akan beragam sesuai dengan perbedaan atribut. Misalnya, seseorang menginginkan besarnya layar monitor. Maka, kepuasan tertinggi akan diperoleh dari monitor paling besar dan kepuasan terendah dari monitor paling kecil. Dengan kata lain, semakin besar ukuran monitor, maka kepuasan juga semakin besar.

5. Konsumen akan sampai pada sikap terhadap merek yang berbeda melalui prosedur evaluasi. Proses evaluasi yang dimaksud adalah aturan kompensasi dan non-kompensasi.

Hawkins, Best, dan Coney (2001) mengatakan bahwa berdasarkan faktor yang yang dipertimbangkan, pengambilan keputusan bisa berdasarkan pada keputusan atribut produk. Pengambilan keputusan yang di dasarkan pada atribut produk ini memerlukan pengetahuan berbagai atribut yang melekat pada produk tersebut, dengan asumsi bahwa keputusan tersebut diambil secara rasional dengan mengevaluasi atribut yang menjadi pertimbangan konsumen. Konsumen didalam membentuk preferensi melalui atribut produk dapat dijelaskan dengan model kompensasi. Model kompensasi adalah model pilihan merek didasarkan pada skor tertinggi ketika kinerja dan bobot penampilan berbagai atribut yang relevan dievaluasi.

Di samping itu, manajemen akan lebih mudah dalam melayani para pelanggannya, jika kondisi pelanggan relatif homogin (Kotler and Keller, 2006). Hal ini bisa dilakukan dengan cara menerapkan kebijakan khusus yang berlaku untuk semua jenis pelanggan. Namun kondisi tersebut hampir tidak mungkin bisa ditemui dalam lingkungan bisnis saat ini. Ketatnya persaingan dan mudahnya pelanggan untuk mengakses informasi adalah contoh yang dapat dijadikan alasan pentingnya organisasi mendekatkan diri kepada pelanggan, melalui studi tentang pemenuhan kebutuhan, keinginan dan harapan-harapan pelanggan yang lain secara spesifik, kelompok demi kelompok.

Konsekuensi manajerialnya adalah kemungkinan organisasi harus melakukan pembedaan perlakuan kepada kelompok- 
kelompok pelanggan atau segmen pasarnya. Hal ini membutuhkan inovasi dan kerja keras manajemen secara terus-menerus. Namun apabila hal itu dapat dilakukan dengan baik, kemungkinan untuk memperoleh hasil yang lebih optimal dapat tercapai.

Ada banyak pendekatan untuk melakukan segmentasi, misalnya berdasarkan faktor-faktor demografi, psikografis, perilaku, pengambilan keputusan dan atau pola medianya. Masing-masing faktor tersebut terdiri dari banyak diskriptor atau rincian, sehingga perlu dipilih yang dipandang relevan sebagai dasar penelitian lebih lanjut (Lilien and Rangaswami, 2003). Pada umumnya operasionalisasi dalam menerapkan pembedaan pelayanan pada setiap segmen lebih mudah dilakukan penjual berdasarkan faktor demografi. Demikian pula apabila dalam menghadapi konsumen notebook.

Sebuah notebook memiliki atribut yang cukup banyak, sehingga kombinasi dari atribut-atribut ini dapat berjumlah ribuan apabila dibuat kombinasinya satu persatu. Kombinasi dari atribut-atribut inilah yang membuat sebuah notebook menjadi kompleks, karena perbedaan antara sebuah notebook dengan notebook tipe lainnya dapat menjadi sangat beragam, yang akhirnya dapat membingungkan konsumen dalam memilih dan melakukan pertimbangan untuk membelinya. Karena itu spesifikasi produk notebook yang ditawarkan oleh produsen biasanya dibatasi dengan menginformasikan atribut-atribut utama atau harus ada pada sebuah notebook, antara lain layar monitor, processor, memory, hard disk, graphics card, konektivitas, fitur/kelengkapan dan sistem operasi.

Berdasarkan pada penjelasan di atas, maka dapat dibuat kerangka penelitian seperti pada Gambar 2.

Mendasarkan pada kerangka penelitian di Gambar 2 tersebut, maka diajukan hipotesis penelitiannya sebagai berikut:

$\mathrm{H}_{1}$ : Terdapat perbedaan preferensi konsumen pada paket spesifikasi notebook sebagai compromise effect berdasarkan pada demografinya.

$\mathrm{H}_{2}$ : Terdapat perbedaan tingkat kepentingan konsumen pada atribut-atribut spesifikasi notebook sebagai compromise effect berdasarkan pada demografinya.

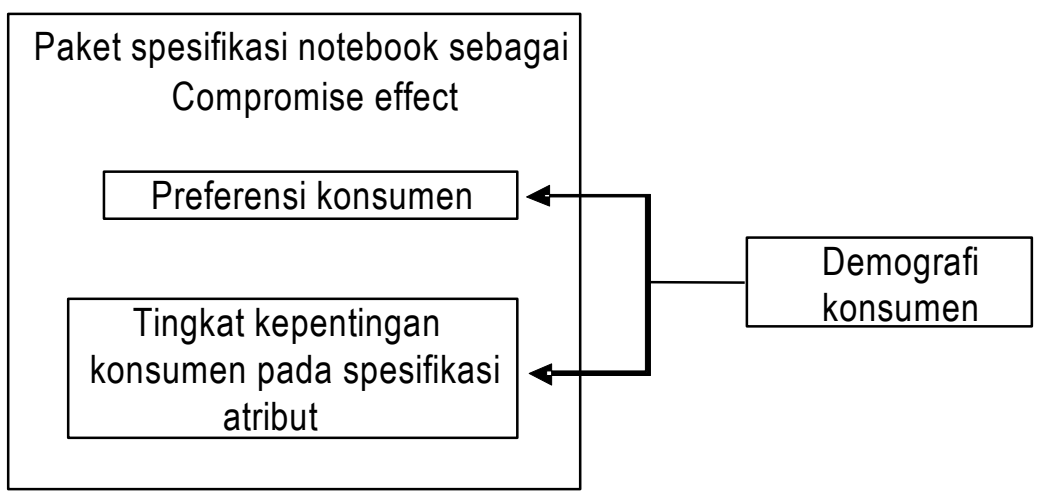

Gambar 2: Kerangka teoritik penelitian 


\section{METODE PENELITIAN}

Subyek penelitian ini adalah konsumen potensial yang belum memiliki notebook. Sedangkan sampel ditentukan secara convenience sampling dari konsumen yang mudah ditemui ketika mereka berada di Kampus Fakultas Teknologi Industri Universitas Islam Indonesia, El's Computer sebagai salah satu distributorterbesar dan terlengkap di Yogyakaarta, serta beberapa tempat dan sarana umum, seperti Galeria Mall dan Ambarukmo Plaza.

Data penelitian berupa data primer dan diperoleh melalui penyebaran angket kepada 96 responden. Angket terdiri dari 3 bagian pernyataan atau pertanyaan. Bagian pertama berisi pernyataan tentang demografi konsumen (gender, usia, status pekerjaan, dan tingkat pendidikan terakhir), dengan menyediakan tanggapan dengan skala nominal dan harus dipilih responden secara mutually exclusive. Bagian kedua berupa daftar tiga paket spesifikasi atribut notebook (paket A-T7500, paket B-T7100, dan paket
C-T5200). Responden diminta untuk memilih satu paket tertentu (diberi skala-1) dan menolak satu paket lain (skala-0) untuk mengetahui preferensi konsumen notebook pada tiga paket spesifikasi yang ditawarkan. Paket spesifikasi tersebut terinci pada Tabel 1.

Bagian ketiga dari angket penelitian berisi pernyataan investigasi terhadap delapan atribut spesifikasi notebook (dari prosesor sampai dengan fitur/kelengkapab) yang terdapat dalam paket yang dijadikan preferensi pada isi angket bagian kedua, sehingga dapat lebih spesifik lagi melihat atribut penting compromise effect konsumen terhadap paket spesifikasi yang ditawarkan. Bagian ketiga ini berupa skala ordinal, dengan cara meminta responden untuk mengurutkan pentingnya delapan atribut spesifikasi notebook utama yang terdapat pada daftar paket yang ada (paket A, B, dan C). Atribut yang paling penting diberi skor 8 , sedangkan yang paling kurang penting diberi skor 1 .

Tabel 1: Paket Spesifikasi Notebook

\begin{tabular}{llll}
\hline \multicolumn{1}{c}{ Atribut } & \multicolumn{1}{c}{$\begin{array}{c}\text { Paket A-T7500 } \\
\text { (Paket Office) }\end{array}$} & $\begin{array}{c}\text { Paket B-T7100 } \\
\text { (Paket mobile) }\end{array}$ & \multicolumn{1}{c}{$\begin{array}{c}\text { Paket C-T5200 } \\
\text { (Paket Multimedia) }\end{array}$} \\
\hline Vendor & HP Presario V3614- & $\begin{array}{l}\text { WEARNES Boldline CNT- } \\
\text { GU002PA }\end{array}$ & $\begin{array}{l}\text { TOSHIBA Satellite A200- } \\
\text { E530 }\end{array}$ \\
Prosesor & Core 2 Duo T7500 & $\begin{array}{l}\text { Core 2 Duo T7100 } \\
\text { Core 2 Duo T5200 }\end{array}$ & 120GB HDD \\
Hard Disk & 160GB HDD & 80GB HDD & 1612MB DDR2 \\
Memori & 512MB DDR2 & 1GB DDR2 & VGA Intel GMA950 256MB \\
Graphic card & VGA Intel GMA X3100 & VGA Nvidia GeForce Go \\
& 358MB (shared) & (shared) & 7300 128MB \\
Monitor & 14.1" WXGA & 12.1" WXGA & 15.4" WXGA \\
Konektivitas & 56K Modem, NIC, WiFi, & 56K Modem, NIC, WiFi, & 56K Modem, NIC, WiFi, \\
& Bluetooth & Bluetooth & Bluetooth \\
Sistem Operasi & Win Vista Home Basic & Non OS & Win Vista Home Premium \\
Fitur/Kelengkapan & 5 in 1 Media Card Reader & Camera & Camera \\
\hline
\end{tabular}

Sumber: http://www.bhinneka.com 
Data yang diperoleh tersebut di atas dianalisis dengan dua pendekatan. Untuk mengidentifikasi perbedaan preferensi konsumen berdasarkan karakteristik mereka digunakan pendekatan chi-square-goodness of fit. Sedangkan untuk menetapkan perbedaan tingkatan pentingnya atribut notebook bagi konsumen berdasarkan perbedaan demografi konsumen dipakai teknik chi-square-independensi. Kedua tahapan analisis tersebut menggunakan taraf signifikansi pengujian ( $\alpha$ ) 5\% serta bantuan program pengolah data Minitab 15.0

\section{HASIL ANALISIS}

\section{Analisis Preferensi Konsumen}

Tahap pertama analisis data dilakukan dengan menentukan proporsi frekuensi pemilihan kombinasi paket spesifikasi notebook, sehingga dapat diketahui kecenderungan keputusan konsumen dengan melibatkan compromise effect. Proporsi frekuensi pemilihan kombinasi tersebut dapat di lihat pada Tabel 2.

Berdasarkan Tabel 2, dapat dinyatakan bahwa konsumen lebih memilih paket B-T7100 dan menolak paket-A maupun paket-C. Hal ini dapat dilihat dari total pilihan konsumen sebanyak 56 orang (9+47) dibandingkan dengan jumlah frekuensi pilihat paket A (20 orang) dan paket C (20 orang). Sehingga dapat dikatakan bahwa konsumen mempertimbangkan paket B-T7100 dari WEARNES Boldline CNT-2011 sebagai paket spesifikasi dengan kategori menengah (compromise effect) di antara 3 paket spesifikasi yang ada.

Tabel 2 juga menginformasikan bahwa preferensi konsumen pada kombinasi ke-4 (pilih B-T7100 - tolak C-T5200) dipilih konsumen dengan frekuensi tertinggi. Karena itu kombinasi tersebut digunakan sebagai dasar untuk menganalisis kemungkinan adanya perbedaan preferensi konsumen pada paket spesifikasi notebook sebagai compromise effect berdasarkan pada karakteristik demografi konsumen (gender, usia, status pekerjaan, dan tingkat pendidikan terakhir). Hasil analisis dengan menggunakan uji chi-square-goodness of fit ditunjukkan pada Tabel 3.

Tabel 2:

Frekuensi Pilihan Kombinasi Paket Spesifikasi Notebook

\begin{tabular}{ccc}
\hline Kombinasi & Preferensi Konsumen & Frequency \\
\hline 1 & Pilih A-T7500 - Tolak B-T7100 & 12 \\
2 & Pilih A-T7500 - Tolak C-T5200 & 8 \\
3 & Pilih B-T7100 - Tolak A-T7500 & 9 \\
4 & Pilih B-T7100 - Tolak C-T5200 & 47 \\
5 & Pilih C-T5200 - Tolak A-T7500 & 11 \\
6 & Pilih C-T5200 - Tolak A-T7100 & 9 \\
\hline & Total & 96
\end{tabular}

Sumber: data primer diolah

Tabel 3: Uji Perbedaan Preferensi Konsumen Menurut Karakteristik

\begin{tabular}{ccccc}
\hline \multirow{2}{*}{ Paket kombinasi } & \multicolumn{4}{c}{ Probabilitas $(\mathrm{p})$} \\
\cline { 2 - 5 } & Gender & Usia & Pekerjaan & Pendidikan \\
\hline Pilih B-T7100 dan Tolak C-T5200 & 0,013 & 0,884 & 0,884 & 0,058 \\
\hline
\end{tabular}

Sumber: data primer diolah 
Tabel 4: Distribusi Preferensi Konsumen Berdasarkan Gender

\begin{tabular}{lccc}
\hline \multirow{2}{*}{ Gender } & \multicolumn{3}{c}{ Jumlah sampel } \\
\cline { 2 - 4 } & Kombinasi & Total & Proporsi \\
\hline Laki-Laki & 32 & 69 & 46,38 \\
Perempuan & 15 & 27 & 55,56 \\
Total & 47 & 96 & --- \\
\hline
\end{tabular}

Sumber: data primer diolah

Berdasarkan hasil pengujian pada Tabel 3, dapat diketahui bahwa terdapat perbedaan preferensi konsumen yang signifikan hanya berdasarkan gender konsumen, karena hasil probabilitas ujinya lebih rendah dari 5\%. Sedangkan untuk uji beda berdasarkan tingkat usia, status pekerjaan dan tingkat pendidikan terbukti tidak signifikan. Karena itu hipotesis pertama diterima untuk kelompok gender konsumen, sedangkan untuk tingkat usia, status pekerjaan dan tingkat pendidikan hipotesis pertama harus ditolak. Selanjutnya, khusus untuk karakteristik gender tersebut dapat diperoleh distribusi kelompok pemilih paket kombinasi tersebut seperti yang terlihat pada Tabel 4.

Tabel 4 tersebut menunjukkan bahwa kelompok laki-laki lebih banyak memilih (32 orang) paket kombinasi ke-4 (pilih B-T7100 - tolak C-T5200) dibandingkan kelompok perempuan (15 orang). Tetapi banyaknya pilihan tersebut karena jumlah sampel penelitian laki-laki juga lebih banyak dibandingkan perempuan. Oleh sebab itu pembandingan lebih tepat menggunakan dasar proporsi. Dengan menggunakan dasar proporsi tersebut ternyata preferensi konsumen paket kombinasi ke-4 cenderung lebih banyak dipilih oleh kelompok konsumen perempuan dibandingkan laki-laki.

\section{Analisis Tingkat Kepentingan Konsumen}

Tahapan analisis ini dilakukan dengan merekapitulasi tanggapan konsumen dalam mengurutkan pentingnya delapan atribut spesifikasi notebook. Hasil perhitungan dapat digunakan untuk mendukung kesimpulan analisis preferensi, atau malah sebalinya. Rekapitulasi perhitungan dari skor rata-rata total ditunjukkan pada Tabel 5 .

Tabel 5: Urutan Kepentingan Atribut Spesifikasi Notebook

\begin{tabular}{clc}
\hline Urutan Kepentingan & \multicolumn{1}{c}{ Atribut } & Skor total \\
\hline 1 & Monitor & 7,49 \\
2 & Prosesor & 6,79 \\
3 & Graphic card & 4,81 \\
4 & Hard disk & 4,38 \\
5 & Memory & 3,96 \\
6 & Sistem operasi & 3,83 \\
7 & Koneksitas & 3,06 \\
8 & Fitur/kelengkapan & 1,68 \\
\hline
\end{tabular}

Sumber: data primer diolah 
Tabel 6: Uji Perbedaan Tingkat Kepentingan Atribut Menurut Karakteristik

\begin{tabular}{lc}
\hline \multicolumn{1}{c}{ Karakteristik Responden } & Probabilitas \\
\hline Gender & 0,820 \\
Tingkat usia & 0,335 \\
Status Pekerjaan & 0,354 \\
Tingkat Pendidikan Terakhir & 0,729 \\
\hline
\end{tabular}

Sumber: data primer diolah

Dari hasil perhitungan skor total pada Tabel 5 tersebut diketahui bahwa monitor menjadi atribut yang dianggap paling penting. Atribut utama tersebut sesuai dengan paket B-T7100, yang mempunyai karakteristik monitor yang paling kecil di antara tiga paket spesifikasi notebook yang ada. Luas ukuran monitor yang kecil cenderung diikuti oleh ukuran notebook yang kecil pula, sehingga notebook tersebut fleksibel bagi konsumen untuk dibawa berpergian dan bisa mendukung aktivitas konsumen dengan mobilitas tinggi, serta gaya hidup konsumen yang lebih mementingkan nilai fashion dan style.

Data urutan kepentingan tersebut juga digunakan untuk menguji perbedaan tingkat kepentingan atribut spesifikasi notebook berdasarkan karakteristik konsumen. Hasil pengujian dengan menggunakan teknik chi-square-independensi tersebut diringkas seperti yang disajikan dalam Tabel 6.

Berdasarkan Tabel 6 tersebut diketahui bahwa tidak ada perrbedaan tingkat kepentingan atribut yang signifikan yang didasarkan pada karakteristik demografi konsumen, baik dari perbedaan gender, tingkat usia, status pekerjaan dan tingkat pendidikan terakhir. Kesimpulan pengujian ini dapat dilihat dari nilai probabilitas hitung yang jauh lebih tinggi dari taraf signifikansi 5\%. Dengan kata lain, hipotesis kedua harus ditolak.

\section{PEMBAHASAN DAN KESIMPULAN}

Hasil-hasil analisis penelitian ini sebagian besar menunjukkan hasil yang saling mendukung. Hasil diskriptif dari preferensi konsumen yang menunjukkan paket B-T7100 lebih banyak dipilih dibandingkan dua paket yang lain, sesuai dengan kesimpulan bahwa paket tersebut lebih disukai oleh kelompok perempuan dibandingkan laki-laki. Pilihan paket tersebut juga didukung oleh tingkat tertinggi kepentingan konsumen pada atribut monitor notebook dengan ukuran kecil. Secara keseluruhan atribut paket B-T7100 bisa dianggap menjadi paket standar yang dapat dikompromikan dalam pilihan konsumen di antara tiga paket spesifikasi yang ditawarkan. Alasan paket ini menjadi kompromi konsumen didukung oleh karakteristik sebagai berikut:

1. Prosesor yang sudah menggunakan teknologi core 2 duo, sama seperti dengan paket A-T7500 dan C-T5200, namun paket ini merupakan paket yang prosesornya memiliki cache memori yang menengah dibandingkan dengan prosesor pada kedua paket lainnya.

2. Memori 1GB, untuk kondisi sekarang ini notebook dengan kapasitas memori 1GB merupakan ukuran standar, dan harga RAM yang semakin menurun dikarenakan teknologi yang terus berkembang mendorong konsumen untuk dapat dengan sendiri menguprade ukuran memori sesuai keinginannya. 
3. Dengan hard disk 80GB, meskipun kapasitas tersebut untuk saat ini tergolong kecil namun trend konsumen yang mengikuti perkembangan teknologi saat ini adalah menggunakan teknologi hard disk eksternal untuk notebook yang harganya sudah relatif murah untuk kapasitas yang besar.

4. Untuk monitor sebagai atribut yang paling dipertimbangkan pada paket BT7100 ini mempunyai ukuran yang kecil, yaitu 12.1" WXGA. Ukuran yang kecil tersebut dapat menunjang aktivitas konsumen yang suka berpergian, tampilan yang lebih minimalis, dan memberikan kesan yang lebih gaya. Ukuran yang kecil juga sangat mungkin lebih disukai oleh kelompok konsumen perempuan.

5. Untuk VGA card, paket ini menggunakan Video Graphic Accelarator standar untuk fungsi-fungsi standar yang disesuaikan dengan layar monitor yang kecil, misalnya untuk aplikasi office, akses internet dan multimedia.

6. Atribut terakhir yang juga menonjol sebagai pertimbangan konsumen adalah sistem operasinya yang tidak terintegrasi dalam paket. Hal ini mendorong kompromi konsumen untuk lebih mempertimbangkannya, sebab selain dikarenakan Windows Vista terbaru masih belum familiar digunakan oleh banyak kalangan, dan banyak aplikasi yang belum banyak didukung oleh Windows Vista, sehingga konsumen masih lebih menyukai proses aktivasi sistem operasi yang lebih familiar seperti windows XP profesional.

7. Untuk fitur atau kelengkapan dan konektivitas, paket ini telah menyediakan kelengkapan dan konektivitas yang memang sesuai untuk semua kalangan, karena pada saat ini akses internet banyak disediakan di tempat- tempat umum, seperti pusat perbelanjaan, Cafe dan anjungan kampus.

Paket B-T7100 yang bisa dinyatakan sebagai paket standar atau menengah yang mungkin dikompromikan dalam pilihan konsumen ini secara empiris mendukung pendapat Kivetz, Netzer, dan Srinivasan (2004a). Mereka mengatakan bahwa jika seorang pengambil keputusan berada dalam keraguan dalam memilih dua atau lebih atribut merek yang sama pentingnya, pemilihan alternatif kompromi yang bisa dilihat sebagai kombinasi antara kedua atribut tersebut mungkin lebih mudah untuk dipertimbangkan. Pilhan kompromi tersebut sekaligus untuk menghindari pilihan atribut yang ekstrim.

Pilihan paket B-T7100 dengan spesifikasi atribut monitor kecil serta tingkat kepentingan tertinggi konsumen terhadap atribut monitor juga mendukung penelitian Kuswanto (2006). Dalam penelitiannya Kuswanto (2006) menyimpulkan bahwa faktor-faktor yang dianggap penting dan mempengaruhi dalam proses pembelian konsumen pada sebuah notebook selain harga, salah satunya adalah berat notebook. Padahal berat-ringannya sebuah notebook banyak berkaitan dengan besar kecilnya ukuran monitor.

Berkenaan dengan hasil tersebut beberapa hal yang perlu diperhatikan dan dapat digunakan sebagai bahan pertimbangan bagi produsen notebook adalah bahwa fenomena compromise effect pada diri konsumen adalah sebuah keniscayaan. Karena itu strategi untuk menghasilkan produk dengan spesifikasi atribut menengah di antara produk yang beredar di pasar dengan spesifikasi atribut ekstrim perlu dipertimbangkan. Khusus untuk notebook, produsen agar lebih memperhatikan kebutuhan konsumen akan notebook yang saat ini lebih banyak untuk menunjang aktivitas sehari-hari dengan tingkat mobilitas yang tinggi, terutama untuk 
konsumen perempuan. Fasilitas yang menunjang fleksibilitas mengakses internet secara bebas dengan teknologi Wi-Fi di tempat-tempat umum juga perlu dipertimbangkan.

Produsen juga perlu melakuakan edukasi dan komunikasi terus menerus tentang teknologi yang berkembang, sebagai informasi yang dapat memberikan wawasan baru dan ketertarikan konsumen atas teknologi terbaru. Sebagai contoh masih banyaknya mahasiswa yang lebih menyukai melakukan aktivasi sistem operasi menggunakan serial windows yang lebih familiar membuka kemungkinan peluang untuk memasukkan teknologi Windows Vista ke dalam sistem operasi yang terintegrasi pada notebook yang ditawarkan.

\section{DAFTAR PUSTAKA}

Bhinneka (2008), Computer Webstore in Indonesia, (Online) Available at http://www.bhinneka.com

Chang, CC. and HH. Liu (2008), Information Format-option Characteristics Compatibility and the Compromise Effect, Psychology \& Marketing, 25 ( 9): 881

Chuang, SC. and HR. Yen (2007), The Impact of a Product's Country-of-origin on Compromise and Attraction Effects, Marketing Letters, 18 (4): 279-292

Chuang, SC., DT. Kao, PH. Wu and CC. Tsai (2007), Aspiration And Compromise Effect, Psychological Reports, 101 (3): 1179-1188

Dhar, R., A. Menon and B. Maach (2004), Toward Extending the Compromise Effect to Complex Buying Contexts, Journal of Marketing Research, 41 (3): 258-261

Hawkins, DI., RJ. Bets and KA. Coney (2001), Consumer Behavior: Building Marketing Strategy, $8^{\text {th }}$ ed., New York: Irwin/McGraw-Hill

Kivetz, R., O. Netzer and V. Srinivasan (2004a), Alternative Models for Capturing the Compromise Effect, Journal of Marketing Research, 41 (3): 237-257.

Kivetz, R., O. Netzer and V. Srinivasan (2004b), Extending Compromise Effect Models to Complex Buying Situations and Other Context Effects, Journal of Marketing Research, 41 (3): 262

Kotler, P. and KL. Keller (2006), Marketing Management, $12^{\text {th }}$ ed., New Jersey: Pearson Prentice Hall

Kuswanto, B. (2006), Penentuan Kombinasi Atribut Produk notebook : Suatu Pendekatan Dengan Conjoint Analysis Terhadap Mahasiswa Di Kota Bandung, Skripsi S1 (dipubilkasikan), Bandung: Jurusan Teknik Industri, Fakultas Teknologi Industri, Universitas Katolik Parahyangan.

Lilien, GL. and A. Rangaswamy (2003), Marketing Engineering, $2^{\text {th }}$ ed., New Jersey: Prentice Hall

Lin, CH., YC. Sun, SC. Chuang and HJ. Su (2007), Time Pressure and the Compromise and Attraction Effects in Choice, Advances in Consumer Research, 35: 348

Lippert, FG. (1979), Quality vs. Productivity, A Compromise?, SuperVision, 41 (1): 16 
Marketing News (2004), Four Models Capture Copromise Effect, 1 September: 39

Mourali, M., U. Bockenholt and M. Laroche (2007), Compromise and Attraction Effects Under Prevention and Promotion Motivations, Journal of Consumer Research, 34: 234-249

Mowen JC. dan M. Minor (1998), Consumer Behavior, $5^{\text {th }}$ ed., New Jersey: Prentice Hall, Inc.

Passavant, P. (1980), Management vs. Creative: the Art of Compromise, Direct Marketing, 43 (2): 24

Sheng, S., AM. Parker and K. Nakamoto (2005), Understanding the Mechanism and Determinants of Compromise Effects, Psychology \& Marketing, 22 (7): 591-609

Simamora, B. (2003), Membongkar Kotak Hitam Konsumen, Jakarta: Penerbit PT Gramedia Pustaka Utama.

Simonson, I. (1989), Choice Based on Reasons: The Case of Attraction and Compromise Effect, Journal of Consumer Research, 16: 158-174.

Wernerfelt, B. (1995), A Rational Reconstruction of the Compromise Effect: Using M, Journal of Consumer Research, 21 (4): 627-634 